\title{
Establishing Learning Commons in University Libraries
}

\author{
An Wang ${ }^{1, a}$, Rongfei $\mathrm{Chu}^{2, \mathrm{~b}}$ and Min $\mathrm{Xu}^{3, \mathrm{c}}$ \\ ${ }^{1}$ Education School, Jiangxi Science \& Technology Normal University, Nanchang, China \\ 2 Jiangxi Science \& Technology Normal University, Nanchang, China \\ 3 Jiangxi Science \& Technology Normal University, Nanchang, China \\ awanganwangmenghua@163.com,,crf7788@163.coml, cxmin8899@163.com
}

Keywords: Information Commons; Learning Commons; challenges; Countermeasure

\begin{abstract}
In order to meet the needs of the interactive study of university students, and to conform to the reform of university educational system, Learning Commons is a new type collaborative learning environment derived from Information Commons in university libraries. The paper analyzes the connotation characteristics and function of the Learning Commons, talks about the challenges of the construction of university library's Learning Commons, studies the construction tactics of Learning Commons.
\end{abstract}

\section{Introduction}

Reform and service becomes the development trend of university library under digital information environment. University library must re-examine and position the role of library in supporting lifelong learning and academic research, and re-determine the function and responsibilities of the library with new concept and mode, so as to adapt to the need of development of university education. Learning common, referred to as LC, meets the need of the reform of university education system and gradually develops on the basis of information common. It combines the digital technology, modern equipment with all kinds of information resources, to provide learning service and reference service, and to cultivate users' autonomous learning ability, information retrieval ability, creative ability, practical skills and other information literacy. LC makes library resources, service and environment into the whole process of learning, guides users to exchange ideas and share wisdom, and promote the study and knowledge creation, in order to adapt to the concept of "lifelong learning" in the era of knowledge economy.

\section{The concept and function of learning common}

Learning common, as a concept, has been discussed by many scholars from different views. The representative is that Donald Beagle holds the learning common not only helps the students manage information, but also helps them manage their learning. Reginal, in the Stanford University, thinks learning common emphasizes knowledge creation space, and provides tools of mutual learning and research for readers, teachers, librarians and workers. To sum up, we hold that, learning common, centered on users, uses rich information resources and advanced technology to organize members to think together, study together and learn collaboratively with the help of subject librarian, so as to realize knowledge sharing and innovation. Its greatest feature is the collaborative learning. It fully supports collaborative learning, encourages interactive learning among members, and gives full play to the collective wisdom.

The function of learning common is to improve users' information literacy, to promote research production to the maximum and to realize intra organizational knowledge sharing and innovation. The members of the organization can search, retrieval, analyze and use information resources with the help of librarians, then their information literacy will be improved gradually in the process; in addition, the tacit knowledge of organization members will also be promoted to transform into explicit knowledge in common discussion and learning, so as to realize knowledge sharing and innovation. Learning common is mainly composed of a physical learning common and a virtual 
learning common. Physic learning common usually includes open learning areas, group learning rooms, multimedia studio, electronic classroom, leisure areas, etc; virtual learning common includes human resources, literature resources, equipment resource, and other kinds of resources.

\section{The challenges of the construction of university library's Learning Commons}

The funds. The learning common covers large area and has numerous modules; its requirement for the computer, cable network and wireless network is rather high, so the entire learning common construction needs substantial funding support. The funds will probably become the chain of creating learning commons in university libraries in Chins. For any domestic university library, taking huge start-up funding one time to construct learning common is indeed difficult. But we can construct university library in domestic study batch by batch and stage by stage on the basis of electronic reading room and consulting research room. In addition to learn the experience from foreign countries, it is also necessary to consider the actual situation of universities, so as to construct learning commons adapting to China's university education.

At present, university librarian troop at domestic is relatively single, and the development of subject librarian is not mature. Subject librarian still need to learn and grasp the frontier knowledge, so it is difficult to provide necessary human resources support for the learning common. In addition, the student assistant librarian system is not perfect and it has no the guidance absorbing graduate students and doctoral students to the museum to learn and research, which exist considerable distance compared with foreign mature learning common.

The problem of teaching atmosphere. Domestic university academic atmosphere is different from the abroad, so as the whole school teaching system and study habits. Teachers pay attention to the scientific research work and can hardly make timely and effective guidance; and students also have not formed good habit of independent learning, which is deviated from the original intention of learning common construction. Therefore, establishing the teaching atmosphere of "teachers lead students and students help each other" is the premise of constructing learning common, otherwise the learning common only has the table.

The problem of management system. Because the learning common integrates a variety of service function, it will integrate different qualities of resources, technology, service and other parties. If learning common is located as a new service management mode of library, it is necessary to establish a new and beneficial cooperation and coordination business process and management methods to guarantee perfect cooperation of the service sector and the construction sector. No matter adopting joint management or independent management, it is always to assure that all service of learning common shall be seamless to users. In order to make the management effective, it is necessary to clear responsibility, establish good user LC feedback channels, match proper human and technical resources, make good communication and reporting system, at the same time, to pay attention to the effect evaluation and to consider finding suitable evaluation mode.

\section{The countermeasures of constructing university learning common}

Implement institutional reform and establish unified information service institutions. The development of digital technology make the library service, information retrieval, knowledge production, and teaching mode increasingly digitized and present the development trend of integration. But the university library, IT department and teaching service sector are still in isolated state, are difficult to play synergistic effect of resources, and can not meet the needs of digital information retrieval and digital learning. In order to adapt to the new development trend, it should promote in-depth integration of library, information technology departments and teaching service departments, and establish unified university information service institutions. Expand the learning commons and integrate teaching management service departments. To continue to promote the horizontal expansion and integrate teaching management center and other teaching service departments, to realize the integration of library services, information technology services and education services. From the vertical, to continue to deepen the service, give full play to synergistic 
effect of mechanism, integrate teaching demonstration, learning object construction, teaching management system construction and implementation and other related work, and provide the literature information service, information technology service and humanized building space for the course construction, knowledge creation, learning guidance and academic exchanges. The learning object is digital resources and printed literature resources which can be reused to support learning.

Improve the quality of librarians and establish reasonable talents. LC staffs in university library are experts from many aspects, such as information technology center, the learning resource center or some famous university academic leaders, etc. they hold meeting monthly to discuss the cooperation service plans, lectures and equipments. This is an important supporting factor to guarantee the teaching and subject research, support technological innovation and complete the task of LC construction. Arranging the LC service personnel reasonably and striving for multi-directional cooperation is the key to the success of the construction of LC. At the same time, LC also should keep relatively fixed relationship with book suppliers, software suppliers and equipment suppliers and maintainers, to guarantee the corresponding of information resources, tool resources, equipment resources, training work and so on. Facing changing information technology and user demand, the library should establish long-term librarian training mechanism and update the knowledge structure of librarians constantly, to meet the high demand of users. The training content should be in accordance with the requirements of specific job. In order to improve the LC talent and knowledge structure layout, it is necessary to open up the broad talent introduction channel and connect social public recruitment with campus cultivation.

\section{Summary}

The libraries should construct the learning common according to the features of library and user demand. Because learning common has no fixed pattern, the libraries can try to explore the mode suitable to their own characteristics and user needs according to their own practice, build learning common in the space, and integrate the concept of learning common in service. Learning common represents the new trend of information service of university library and will have far-reaching impact on service innovation of libraries.

\section{References}

[1]Santa Clara University. Learning commons \& Library [ EB/OL ] . [ 2012-09-10 ]. http://www.scu.edu/newlibrary/.

[2] Haas L,Robertson J. The information commons [M] .Washinton D C. Association of Research Libraries,2004.

[3] Polanyi M.Personal knowledge:Towards a post critical philosophy[D].Chicago:University of Chica-go Press,1974:21-25.

[4] Beatty S,White P. Information commons:Models for eLiteracy and the integration of learning[ $\mathrm{J}]$. Journal of e-Literacy,2005,2(1):2-14.

[5] Elizabeth B Fitzpatrick,Anne C Moore,Beth W Lang. Reference Librarians at the Reference Desk in a Learning Commons:A Mixed Methods Evaluation $[\mathrm{J}]$. The Journal of Academic Librarianship,2008,34(3):231-238.

[6]Loertscher,David V.; Koechlin,Carol. The Virtual Learning Commons and School Improvement. Teacher Librarian,2012,(6):20-24.

[7]Heitsch,Elizabeth K.; Holley,Robert P. The Information and Learning Commons:Some Reflections. New Review of Academic Librarianship,2011,(1):64-77.

[8] Bennett S. The Information or the learning commons:Which Will We Have? [ J]. The Journal of Academic Librarian-ship,2008(3):183-185. 
[9] Nancy Schmidt,Janet Kaufman. Learning Commons:Bridging the academic and student affairs divide to enhance learning across campus [J] . Research Strategies,2007(20):242-256. 